\title{
Stingless Bees (Hymenoptera, Apoidea, Meliponini) from Gabon
}

\author{
Edgard Cédric Fabre Anguilet, Taofic Alabi, \\ Bach Kim Nguyen, Toussaint Ndong Bengone, \\ Éric Haubruge, and Frédéric Francis
}

\subsection{Introduction}

Stingless bees are highly eusocial and are distributed in tropical and subtropical areas worldwide (Michener 2007). Africa is a region with a low richness of stingless bee species. For example, 22 stingless bee species have been recorded in Africa (Table 13.1) versus approximately 400 species in tropical America (Camargo and Pedro 2008). In Africa, stingless bees have been found in the sub-Sahara, with the greatest diversity occurring in Central Africa (Fabre Anguilet et al.

\footnotetext{
E.C. Fabre Anguilet $(\bowtie)$

University of Liege - Gembloux Agro-Bio Tech.

Functional and Evolutionary Entomology,

Passage des Déportés 2, BE-5030 Gembloux, Belgium
}

Centre National de la Recherche Scientifique et Technologique (CENAREST), Institut de Recherches Agronomiques et Forestières (IRAF), Trois Quartier B, 3090 Libreville, Gabon e-mail: efabre@doct.ulg.ac.be; efabreanguilet@ gmail.com

T. Alabi • B.K. Nguyen • É. Haubruge • F. Francis University of Liege - Gembloux Agro-Bio Tech. Functional and Evolutionary Entomology, Passage des Déportés 2, BE-5030 Gembloux, Belgium

T. Ndong Bengone

Centre National de la Recherche Scientifique et Technologique (CENAREST), Institut de Recherches Agronomiques et Forestières (IRAF),

Trois Quartier B, 3090 Libreville, Gabon
2015). Indeed, the Congo Basin forest constitutes a habitat where several African species are commonly encountered. Consequently, a number of African species have been identified in Gabon (see Fig. 13.1) (Pauly 1998; Eardley 2004; Eardley and Urban 2010; Fabre Anguilet et al. 2015).

Bees contribute to the pollination of native and crop plants (Michener 2007); thus, stingless bees are potentially efficient pollinators of crops like coffee (Coffea), avocado (Persea), and safou (Dacryodes) (Tchuenguem et al. 2001, 2002; Slaa et al. 2006; Munyuli 2014). Rural human populations also use honey and cerumen for traditional practices in Gabon. Consequently, stingless bees have important ecological, economic and cultural roles in these regions.

The abundance, ecology, nesting behaviour, nest structure and taxonomy of stingless bees have been studied in several African countries; however, clarification is required due to the presence of cryptic species, which are species that are morphologically similar and may only be distinguished by fine morphological characteristics (Michener 2007). The nest structure is also used to distinguish different species of stingless bees (Roubik 2006). Some species were reclassified by Eardley (2004) but were later re-established by Pauly and Fabre Anguilet (2013). The use of morphological identification associated with molecular tools for cryptic species could help resolve taxonomic and phylogenetic issues (Hoy 2013), allowing the taxonomy of African stingless bees 
Table 13.1 Stingless bee fauna recorded in Gabon (Darchen and Pain 1966; Brosset and Darchen 1967; Darchen 1969; Pauly 1998; Eardley 2004; Pauly and Fabre Anguilet 2013; Pauly and Hora 2013)

\begin{tabular}{|c|c|}
\hline African species & Species recorded in Gabon \\
\hline Cleptotrigona cubicep (Friese 1912) & $x$ \\
\hline Dactylurina staudingeri (Gribodo 1893) & $x$ \\
\hline \multicolumn{2}{|l|}{ Dactylurina schmidti (Stadelmann 1895) } \\
\hline Hypotrigona araujoi (Michener, 1959) & $x$ \\
\hline Hypotrigona gribodoi (Magretti 1884) & $x$ \\
\hline Hypotrigona ruspolii (Magretti 1898) & $\times$ \\
\hline \multicolumn{2}{|l|}{ Hypotrigona squamuligera (Benoist 1937) } \\
\hline Meliponula (Meliplebeia) beccarii (Gribodo 1879) & $x$ \\
\hline Meliponula (Meliponula) bocandei (Spinola 1853) & $x$ \\
\hline Meliponula (Axestotrigona) cameroonensis (Friese 1900) & $x$ \\
\hline Meliponula (Axestotrigona) erythra (Schletterer 1891) & $\times$ \\
\hline Meliponula (Axestotrigona) ferruginea (Lepeletier 1841) & $x$ \\
\hline \multicolumn{2}{|l|}{ Meliponula (Meliplebeia) griswoldorum Eardley 2004} \\
\hline Meliponula (Meliplebeia) lendliana (Friese 1900) & $x$ \\
\hline Meliponula (Meliplebeia) nebulata (Smith 1854) & $x$ \\
\hline Meliponula (Meliplebeia) roubiki Eardley 2004 & $x$ \\
\hline Meliponula (Axestotrigona) togoensis (Stadelman 1895) & $x$ \\
\hline \multicolumn{2}{|l|}{ Liotrigona bottegoi (Magretti 1895) } \\
\hline Liotrigona bouyssoui (Vachal 1903) & $x$ \\
\hline Liotrigona gabonensis Pauly and Fabre Anguilet 2013 & $x$ \\
\hline \multicolumn{2}{|l|}{ Liotrigona baleensis Pauly and Hora 2013} \\
\hline Plebeina armata (Magretti 1895) & \\
\hline
\end{tabular}

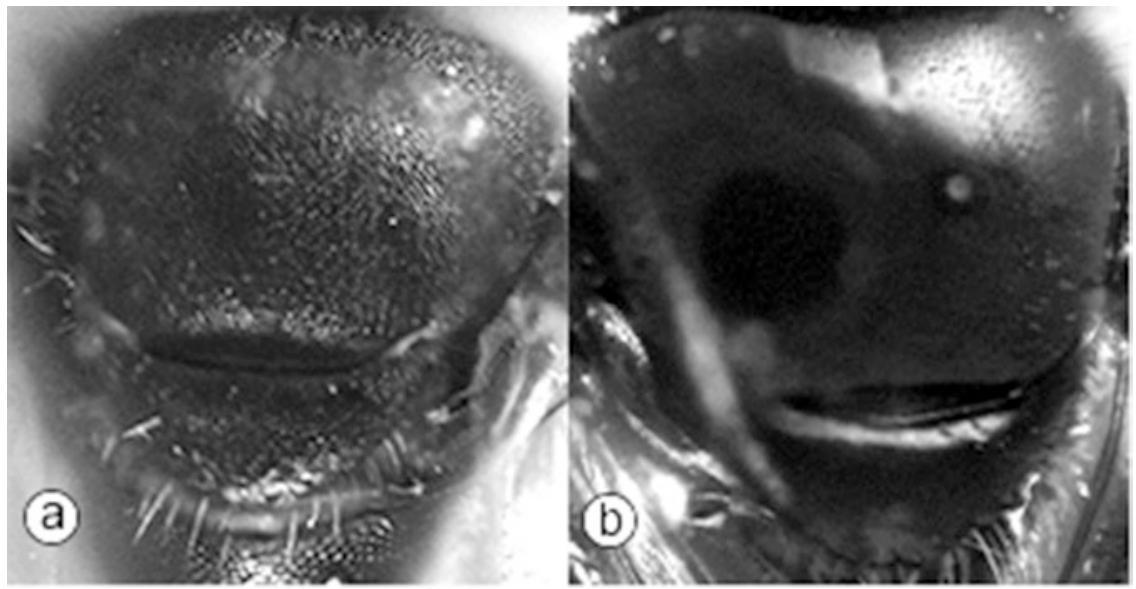

Fig. 13.1 Scutum and scutellum: (a) Hypotrigona gribodoi and (b) Liotrigona gabonensis (Photo: E.C. Fabre Anguilet (C) Fabre Anguilet E. C., 2016) 
to be agreed upon. DNA barcoding is one of the methods used to distinguish species of bees. For instance, Koch (2010) demonstrated the existence of a new species of Western Malagasy Liotrigona in addition to the three already described species using morphometry and DNA barcoding.

Seventy-eight percent of the territory of Gabon is covered by rainforest, of which a great part is exploited by logging companies (Drouineau and Robert 1999; Fabre Anguilet et al. 2015). In addition, there are mining concessions, oil concessions and, essentially, rural agricultural practices. Stingless beekeeping is not practised and beekeeping using Apis mellifera is scarce. As a result, some beekeeping projects have been initiated by the Food and Agriculture Organization of the United Nations (FAO), National Higher Institute of Agronomy and Biotechnology (INSAB) and private companies, such as COLAS Gabon. To date, these projects have failed to achieve a wide dissemination or popularity in Gabon.

However, some initiatives in the sustainable management of biodiversity resources have been implemented. For example, the establishment of protected areas or sustainable management plans of forest resources by logging companies. These initiatives primarily take into account the sustainable management of flora and large mammals, due to the existence of significant scientific works. However, bees, particularly stingless bees, are rarely incorporated into these initiatives. Thus, research is needed to improve our understanding of the biology, ecology and diversity of stingless bees in Gabon, along with the impact of different human activities. To achieve this, the current status of stingless bees must be established. Here, we provide an overview of the diversity, distribution, biology, ecology and traditional knowledge and uses of stingless bees in Gabon.

\subsection{Taxonomy and Morphological Diversity of Stingless Bees in Gabon}

In Gabon, 16 stingless bee species have been listed (see Fabre Anguilet et al. 2015). These species are divided into five genera: Cleptotrigona,
Dactylurina, Meliponula, Hypotrigona and Liotrigona (see Table 13.1).

These species were determined based on morphological characteristics and nest structure (see Sect. 13.4). Eardley (2004), Michener (2007), Pauly and Fabre Anguilet (2013) and Pauly and Hora (2013) provide full descriptions of stingless bee species encountered in Gabon. Thus, only a few of the main morphological characteristics are presented here.

There are two general size categories of stingless bees: species with small body size and relatively large stingless bees. Small bees generally have a body length less than $5 \mathrm{~mm}$. This group includes $C$. cubiceps, $H$. araujoi, $H$. gribodoi, $H$. ruspolii, L. bouyssoui and L. gabonensis. These species have a dark-coloured integument, with a metasoma ranging from black to orange-yellow in colour (Eardley 2004; Michener 2007). Hypotrigona and Liotrigona have forewings with a few veins. Some cryptic species may be present in these and ratios to distinguish some species (Eardley 2004). Liotrigona resemble Hypotrigona but may be differentiated by a few morphological characteristics. For instance, the scutum of Liotrigona is smooth, shiny and sparsely punctate, while that of Hypotrigona is dull and densely punctate (Eardley 2004; Eardley et al. 2010; see Fig. 13.1). Dactylurina and Meliponula include species of intermediate to large body size. These species have a body length of 5-9 mm. Dactylurina staudingeri has a black integument, slender body and weakly plumose vestiture (Eardley 2004; Michener 2007). This species has forewings with a faintly black colour. The Meliponula are further subdivided into three subgenera: Meliponula, Axestotrigona and Meliplebeia (Eardley et al. 2010). Meliponula bocandei is the only species classified in the subgenus Meliponula. The integument of this species varies from black to red-black in colour, with orange and yellow-orange areas (Eardley 2004). The M. (Axestotrigona) subgenus includes species that lack yellow markings (M. cameroonensis, M. erythra, M. ferruginea and M. togoensis), while Meliplebeia have yellow markings on the face (M. beccarii, M. lendliana, M. nebulata and M. roubiki) (Eardley 2004; Eardley et al. 2010). In addition, $M$. lendliana has yellow markings on 
the proximal ends of the tibiae, whereas $M$. nebulata has black markings on the tip of the forewings (Pauly 1998).

\subsection{Distribution of Stingless Bee Fauna in Gabon}

Stingless bees are distributed throughout Gabon. Forests cover approximately $78 \%$ of the territory in Gabon (Drouineau and Robert 1999). The vegetation is essentially composed of secondary forests, dense primary forests, riparian forests, humid forests, gallery forests and savannahs (Drouineau and Robert 1999; Ambougou Atisso 1991). There are three climatic areas in Gabon: equatorial climate in the north, tropical climate in the south and a transition zone between the two (Drouineau and Robert 1999) (see Fig. 13.2). The equatorial climate is marked by two dry seasons per year, the tropical climate by 5 months of dry season and 7 months of rainy season and the transition zone between both by 3 months of dry season and 9 months of rainy season (Drouineau and Robert 1999). In general, the climate in Gabon is characterized by average annual rainfall greater than $1500 \mathrm{~mm}$ (range: $1200-3000 \mathrm{~mm}$ ) and $25{ }^{\circ} \mathrm{C}$ average annual temperature (range: 22-30 ${ }^{\circ} \mathrm{C}$ ) (Maloba Makakanga and Samba 1997; Drouineau and Robert 1999; Tsalefac et al. 2015). The soils are classified in the subclass of ferralitic soils highly desaturated (Chatelin 1968). The relief is characterized by a lack of high elevation (the highest peaks reach approximately $1000 \mathrm{~m}$ ) and a low frequency of steep slopes (Drouineau and Robert 1999).

However, there is no published work considering distribution patterns of stingless bees based on vegetation cover or climate for equatorial Africa in general, including Gabon. Stingless bees have only been studied in a few locations in Gabon. For example, Brosset and Darchen (1967), Darchen (1966, 1969, 1973, 1977), Darchen and Pain (1966) and Ambougou Atisso (1990) studied the biology, ecology, nesting, nest structure and pollen composition of food reserves of stingless bees in Belinga and Makokou (eastern part of Gabon). Only Pauly (1998) studied the distribution of stingless bees across this country between 1984 and 1987. Several species of stingless bee are widely distributed in Gabon (Pauly 1998; Eardley 2004; Pauly and Fabre Anguilet 2013) (see Fig. 13.2). Thus, C. cubiceps, D. staudingeri, H. gribodoi, L. bouyssoui, L. gabonensi, M. bocandei, M. nebulata and M. togoensis are distributed across numerous locations, whereas $M$. cameroonensis is only distributed in the eastern part of Gabon, while M. lendliana is most common in the western part of this country (Pauly 1998). When climatic zones are superimposed with the localities studied by Pauly (1998) (see Fig. 13.2), the climate transition zone has the highest species richness and the largest distribution of species. This phenomenon might be explained by two factors. First, forests constitute the preferred habitat of stingless bees (Brosi et al. 2008), and this climatic zone is largely covered by forests, unlike the tropical climatic zone, which is partly covered by gallery forests and savannah. Second, more locations were investigated in the transition climatic zone compared to the other two climate zones. This issue might explain the greater species richness and species distribution detected within the transition climatic zone.

Future studies should update knowledge about the distribution of stingless bees in Gabon to establish how human activities influence the habitats of stingless bees. For example, logging persists in about $51 \%$ of the territory of Gabon (Fabre Anguilet et al. 2015), and populations practise the clearing of the forest for the food crops. These activities are practised for many decades and might alter habitats, which, in turn, would impact stingless bee population dynamics. For instance, the species richness of stingless bees has declined substantially over the last three decades at Kougouleu (Fabre Anguilet, in preparation). Pauly (1998) identified eight stingless bee species in this location. Today, $60 \%$ of the Meliponula genus is no longer observed at Kougouleu, while the species that are still present occur at low frequency. This decline is probably linked to increasing habitat disturbance by human activities at this location. Indeed, the forests at Kougouleu have been subject to forest clearance, 

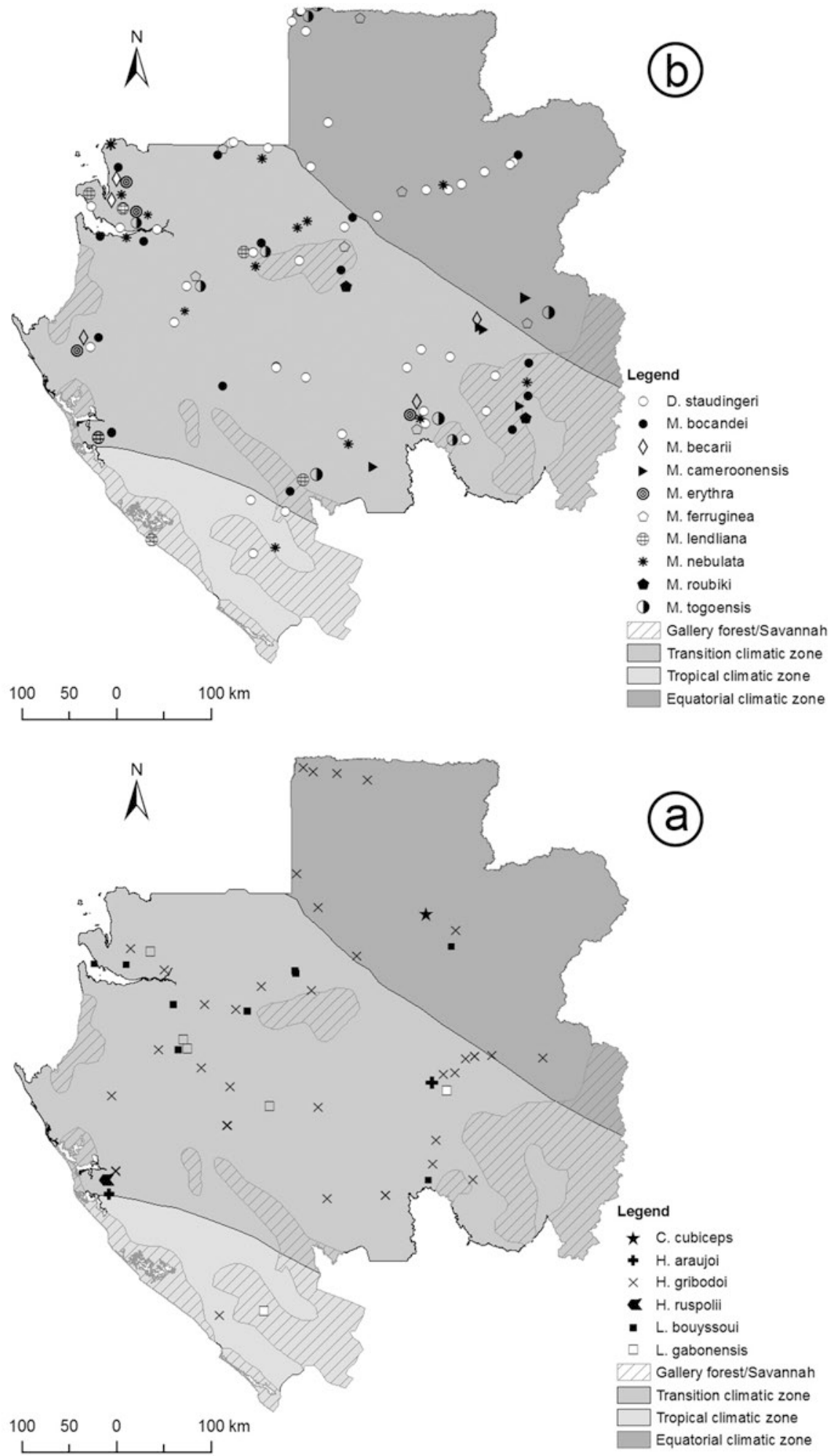

Fig. 13.2 Diversity of stingless bee fauna in Gabon: (a) Species with small body size, (b) species with larger body size (Modified from E.C. Fabre Anguilet et al. 2015) 
Fig. 13.3 The change in metasomal coloration and length of $M$. nebulata: (a) at 1 day, (b) at 6 days, (c) at 13 days, (d) at 17 days and (e) at 28 days (Modified by E.C. Fabre Anguilet from Darchen 1969)

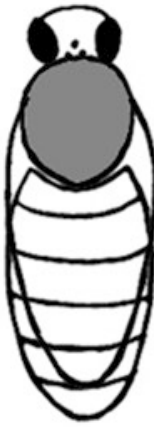

a
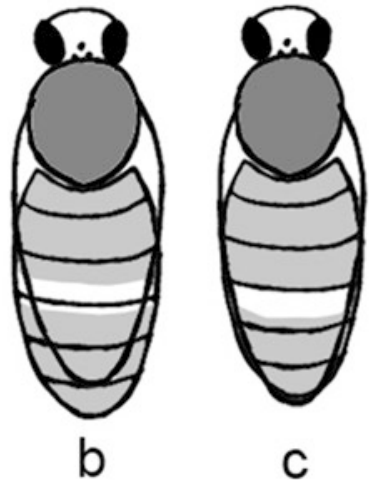

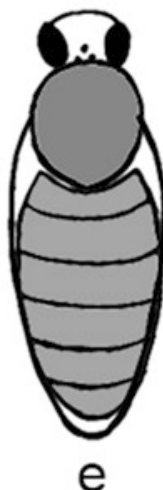

with forests being replaced with food crops. This huge pressure for food crops to replace forest habitats is linked to an increase in human populations in the province of Estuaire in Kougouleu. For instance, the population expanded from 102,577 inhabitants in 1970 to 895,689 inhabitants in 2013 (Lopez-Escartin 1991; Direction Générale de la Statistique 2015). These populations clear the forest, mostly along main roads, to establish crops.

Agribusinesses have also been set up, such as OLAM. No data have been published on how these agribusinesses impact pollinators, particularly bees in Gabon. The results obtained by Fabre Anguilet (Fabre Anguilet et al., unpublished data), along with those obtained 30 years earlier by Pauly (1998), show that logging has had no effect on the species richness of stingless bees in the concession of Precious Wood Gabon. This logging activity is conducted according to sustainable management rules, which include 25 -year rotations. A better knowledge of the distribution and diversity of stingless bees and other pollinators would enhance their integration in sustainable management strategies of natural resources in Gabon.

\subsection{Biology, Ecology and Nesting Behaviour of the Stingless Bees}

The biology of stingless bee species in Africa has been poorly documented. The life cycle of these species is similar to that of other social species.
In brief, four steps exist: egg (fertilized egg to the new queens or workers), larva, pupa and adult stage (Kwapong et al. 2010). Workers exhibit age-based morphological differences. For instance, the metasoma colouring of $M$. nebulata varies from light to dark red-orange depending on age, with the length of the abdomen compared to the forewings also changing with age (Darchen 1969; see Fig. 13.3).

Reproduction in stingless bee colonies takes place in several steps. First, workers build the new nest. Then, an unmated queen (still capable of flight) and part of the colony occupy the new nest (Oliveira et al. 2013). Darchen (1977) described four steps in the occupation of a new nest by $H$. gribodoi in Gabon. First, the old workers begin to build a tubular entrance inside the new nest. Second, young workers join the old workers to continue nest building and to build food storage pots. Third, the new nest is occupied by a large number of young workers. Fourth, the virgin queen joins the new nest with the young workers.

Only Ambougou Atisso (1990) has published a study analysing the pollen in the food reserves of stingless bees. This study highlighted the presence of 14 types of pollen in the food reserves of Hypotrigona during the dry season in forest area of Makokou in the north-eastern part of Gabon.

Although forest and tree cavities constitute the preferred nesting habitat of stingless bees in Gabon, species such as $H$. gribodoi and $D$. staudingeri also nest in anthropogenic settings, such as buildings. Hypotrigona gribodoi nests in the cavities of the walls of houses (see Fig. 13.4), 

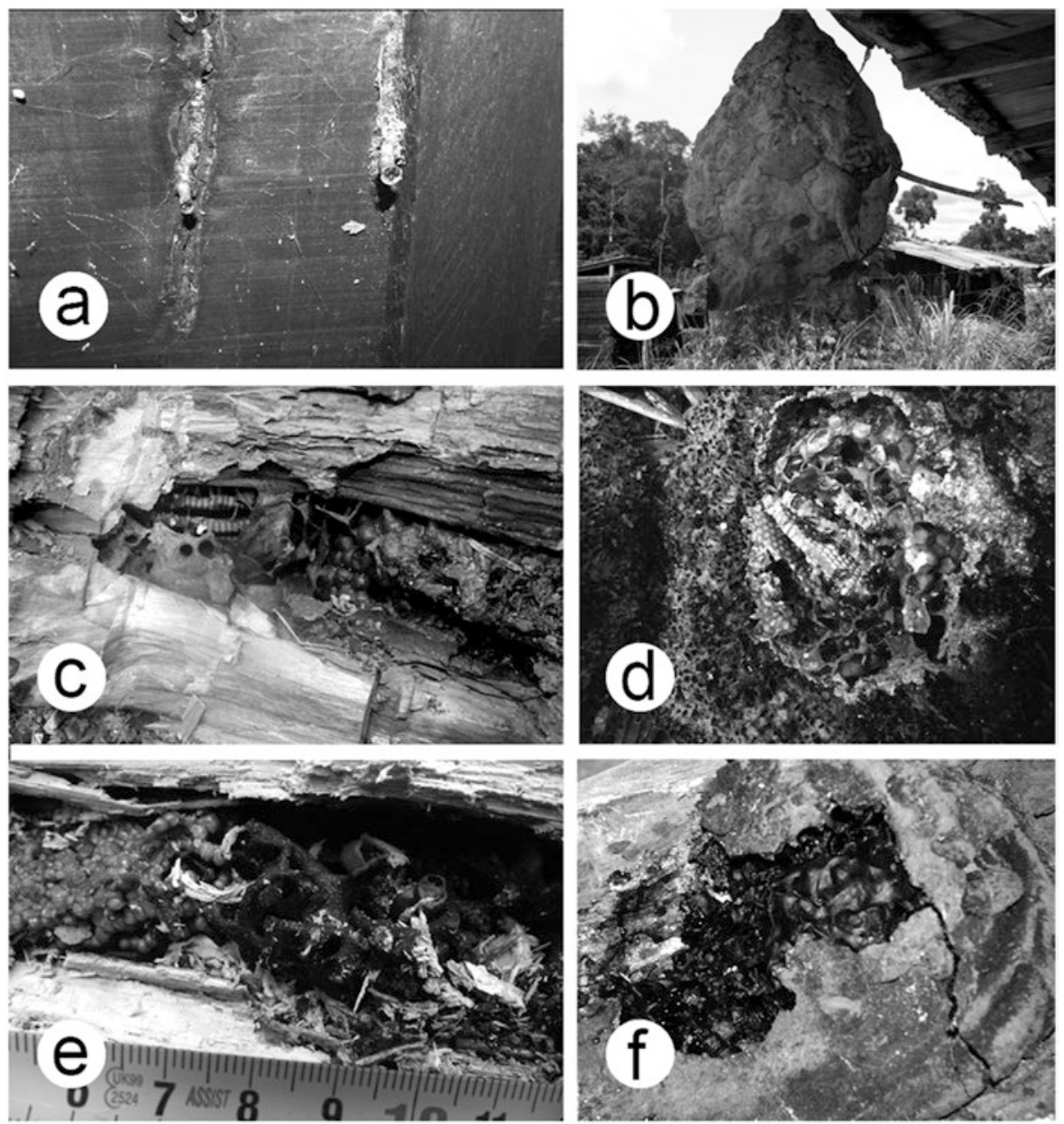

Fig. 13.4 Nests of stingless bees: (a) Hypotrigona in the wall of a house, (b) nest of Dactylurina staudingeri, (c) nest of Meliponula nebulata in a termite mound, (d) nest of Meliponula nebulata in a tree, (e) nest of Liotrigona gabonensis in a tree and (f) nest of Meliponula ferruginea in a tree (Photo: E.C. Fabre Anguilet (C) Fabre Anguilet E. C., 2016)

1954; Darchen 1969; Njoya 2009; Pauly and Fabre Anguilet 2013). Meliponula bocandei is the largest African stingless bee and occupies both the ground cavities and tree cavities of Uganda (Kajobe and Roubik 2006). Wille (1983) observed that relatively few stingless bee species build nests in underground cavities. Examples include M. nebulata in Gabon and M. beccarii and M. lendliana in Africa (Smith 1954; Portugal-Araujo 1963; Darchen 1969). Stingless bees also nest in unoccupied termite mounds, in the cavities left by colonies that have died (Darchen 1969; see Figure 4). Termite mounds provide a shelter that allows

\begin{abstract}
air circulation for the nests of stingless bees
\end{abstract}
potrigona, Liotrigona, M. bocandei, M. nebulc M. ferruginea, M. erythra and M. togoensis (Smith 
(Darchen 1969). Hypotrigona, Cleptotrigona, M. nebulata and M. beccarii have been observed nesting in termite mounds (Darchen 1969). These bees also benefit from cavities excavated by birds and pangolins. The nests of Crematogaster ants are also occupied by M. erythra (Darchen 1969, 1971). Overall, the nesting biology of stingless bees varies in Gabon, as it does in other parts of the world (Roubik 2006).

\subsection{Knowledge and Traditional Use of Stingless Bees in Gabon}

Beekeeping with Apis mellifera for honey is not practised much in Gabon, and there is no meliponiculture. Rural populations mainly practice honey hunting. In general, only the honey is harvested, with all other products of the colony being thrown away. This activity has a cultural basis and is passed from one generation to the next. Indeed, Central African populations, especially those of Gabon, have a long history of hunter-gatherer-fishers (Oslisly 1998). The honey of stingless bees is primarily used for medicinal purposes. For instance, the honey produced by $M$. bocandei and M. nebulata is used to treat respiratory and stomach diseases. The honey collected through honey hunting appears to have been sufficient to satisfy the demand of traditional healers. As a result, rural populations have, perhaps, not seen the need to practice meliponiculture. Rural populations also retrieve the wild nests of D. staudingeri suspended from tree branches to suspend them on the walls of houses (see Fig. 4b; Darchen 1966). This practice is related to a local belief that the workers of $D$. staudingeri will protect the occupants of a house against people with malicious intentions.

Vernacular names are used in rural communities. For example, "Abè" is the name used for eusocial bees in the vernacular language of Fang. "Libundu" and "Lévéki" are the names used for stingless bees in the vernacular languages of Ndumu and Nzébi. "Divasou" and "Mvem" are the names used for Hypotrigona in the vernacular languages of Punu and Fang. Meliponula bocandei is called "Dibouga" in the vernacular language Punu. However, two names are popular: "sweet honey" for M. bocandei and "sour honey" for honey produced by other stingless bees. Information remains limited on the knowledge of rural populations about stingless bees, because no work has been published on this subject in Gabon.

Darchen (1969) transferred M. nebulata to hives for stingless bees. Fabre Anguilet et al. (2017) also transferred M. bocandei to hives. These trials demonstrated the difficulties of setting up meliponiculture in Gabon. The transfers carried out by Darchen led to the bees deserting from the hives, due to the presence of fungi and parasites (phorids, other Diptera and Coleoptera). Similarly, the colonies of transferred M. bocandei were destroyed by the larvae of the small beetle hive Aethina tumida. These problems are also common in other African countries. For example, in Uganda, Nkoba (2012) identified A. tumida as a threat to stingless bees transferred to hives.

\subsection{Conclusion}

Gabon has one of the highest diversities of stingless bees in Africa. Species richness in this country must be further studied, because the taxonomy needs clarification, particularly for Hypotrigona and Liotrigona. The use of morphological methods coupled with molecular methods will facilitate this process. Stingless bees are common throughout Gabon, with the exception of a few species. Nesting behaviour varies within and across species. The effect of the exploitation of natural resources, such as logging, on the habitat and distribution of stingless bees in Gabon needs to be monitored, because most bee species nest in forest habitats and, therefore, depend on this resource.

To introduce and popularize stingless beekeeping in Gabon successfully, first, certain research is required. Information on thermoregulation, the splitting of colonies and control mechanisms against pests and enemies of stingless bees needs to be acquired. The study of the organoleptic and physicochemical characteristics 
of the honey of stingless bees in Gabon would also enhance its value in Gabon. At present, knowledge remains limited on stingless bees in Gabon, yet, they have the potential to provide economic benefits to local communities, provided appropriate knowledge is acquired. Targeted research on understanding the biology and meliponiculture is therefore required.

Acknowledgements The authors thank the Gabonese government and the Commission Economique du Bétail, de la Viande et des Ressources Halieutiques for their financial support and the Agence Nationale des Parcs Nationaux and Precious Woods Gabon for logistical support.

\section{References}

Ambougou Atisso V. 1990. Analyse pollinique des réserves alientaires d'Apis mellifera adansonii L. et d'Hypotriogona sp (Hym. Apidae sociaux de la région de Makokou (N-E) Gabon). Bulletin de la société Botanique de France 137, Actualité Botanique 2: 166-169.

Ambougou Atisso V. 1991. Apis mellifera adansonii Lat. et les plantes utiles mellifères gabonaises (Département de l'Ivindo), recherches palynologiques. Thèse de doctorat, Université Paris 6 ; Paris, France. 160 pp.

Brosi BJ, Daily GC, Shih, TM, Oviedo F, Durán G. 2008. The effects of forest fragmentation on bee communities in tropical countryside. Journal of Applied Ecology 45: 773-783.

Brosset A., Darchen R. 1967. Une curieuse succession d'hôtes parasites des nids de Nasutitermes. Biologia Gabonica 3: 153-168.

Camargo JMF, Pedro SRM. 2008. Meliponini Lepeletier, 1836. In Moure JS, Urban D, Melo GAR, eds. Catalogue of Bees (Hymenoptera, Apoidea) in the Neotropical Region - online version. Available at: http://www.moure.cria.org.br/catalogue .

Chatelin Y. 1968. Notes de pédologie gabonaise. V-géomorphologie et pédoloie dans le Sud Gabon, des Monts Birougou au Littoral. Cahiers ORSTOM Série pédologie 6: 3-20.

Darchen R. 1966. Sur l'éthologie de Trigona (Dactylurina) staudingeri Gribodoi (sic) (Hymenoptera Apidae). Biologia Gabonica 2: 37-45.

Darchen R. 1969. Sur la biologie de Trigona (Apotrigona) nebulata komiensis Cock. I. Biologia Gabonica 5: 151-183.

Darchen R. 1971. Trigona (Axestotrigona) oyani Darchen (Apidae, Trigoninae), une nouvelle espèce d'abeille africaine - description du nid inclus dans une fourmilière. Biologia Gabonica 7: 407-421.

Darchen R. 1973. La thermorégulation et l'écologie de quelques espèces d'abeilles sociales d'Afrique (Apidae, Trigonini et Apis mellifica var. adansonii). Apidologie 4: 341-370.

Darchen R. 1977. L'essaimage Chez Les Hypotrigones au Gabon dynamique de quelques populations. Apidologie 8: 33-59.

Darchen R, Pain J. 1966. Le nid de Trigona (Dactylurina) staudingeri Gribodoi (sic) (Hymenoptera: Apidae). Biologia Gabonica 2: 25-35.

Direction Générale de la Statistique 2015. Résultats globaux du Recensement Général de la Population et des Logements de 2013 du Gabon (RGPL2013). Libreville. 195 pp. Available at http://www. mays-mouissi.com/wp-content/uploads/2016/07/ Recensement-general-de-la-population-et-deslogements-de-2013-RGPL.pdf

Drouineau S, Robert N. 1999. L'aménagement forestier au Gabon : historique, bilan, perspectives.. Available at http://forafri.cirad.fr/ressources/forafri/08.pdf

Eardley CD. 2004. Taxonomic revision of the African stingless bees (Apoidea: Apidae: Apinae: Meliponini). Plant Protection 10: 63-96.

Eardley CD, Urban R. 2010. Catalogue of Afrotropical bees (Hymenoptera: Apoidea: Apiformes). Zootaxa 2455: 1-548.

Eardley CD, Kuhlmann M, Pauly A. 2010. Les genres et sous-genres d'abeilles de l'Afrique subsaharienne. ABC Taxa 9: 1-144.

Fabre Anguilet EC, Nguyen BK, Bengone Ndong T, Haubruge E, Francis F. 2015. Meliponini and Apini in Africa (Apidae: Apinae): a review on the challenges and stakes bound to their diversity and their distribution. Biotechnologie, Agronomie, Société et Environnement, 19: 382-391.

Fabre Anguilet EC, Alabi T, Haubruge E, Nguyen BK, Bengone Ndong T, Francis F. 2017. Parasitisme d'Apis mellifera adansonii (Latreille 1804) et de Meliponula bocandei (Spinola 1853) par Aethina tumida (Murray 1867): premier recensement au Gabon et impact sur la domestication. Entomologie Faunistique 70: 3-11.

Hoy M. 2013. Insect molecular genetics, an introduction to principles and applications, 3rd Ed. Academic Press; San Diego, USA. 840 pp.

Kajobe R, Roubik, DW. 2006. Honey-making bee colony abundance and predation by apes and humans in a Uganda forest reserve. Biotropica 2: 210-218.

Koch H. 2010. Combining Morphology and DNA Barcoding Resolves the Taxonomy of Western Malagasy Liotrigona Moure, 1961 (Hymenoptera: Apidae: Meliponini). African Invertebrates 51: 413-421.

Kwapong P, Aidoo K, Combey R, Karikari A. 2010. Stingless Bees - importance, management and utilization: a training manual for stingless beekeeping. Unimax Macmillan Ltd; Accra, Ghana. 72 pp. 
Lopez-Escartin N. 1991. Données de base sur la population : Gabon. Centre Français sur la Population et le Développement. Paris, France. 11 pp.

Maloba Makakanga JD, Samba G. 1997. Organisation pluviométrique de l'espace Congo-Gabon (19511990). Sécheresse $8: 39-45$.

Michener CD. 2007. The bees of the world, second edition. Johns Hopkins University Press; Baltimore, USA. 953 pp.

Munyuli T. 2014. Influence of functional traits on foraging behaviour and pollination efficiency of wild social and solitary bees visiting coffee (Coffea canephora) flowers in Uganda. Grana 53: 69-89.

Njoya MTM. 2009. Diversity of Stingless Bees in Bamenda Afromontane Forests - Cameroon: Nest architecture, Behaviour and Labour calendar. Dissertation, Hohen Landwirtschaftlichen Fakultät der Rheinischen Friedrich-Wilhelms-Universität zu Bonn, 138 pp.

Nkoba, K. 2012. Distribution, behavioural biology, rearing and pollination efficiency of five stingless bee species (Apidae: Meliponinae) in Kakamega forest, Kenya. Kenyatta University; Nairobi, Kenya. 237pp.

Oliveira RC, Menezes C, Soares AEE, Fonseca VLI. 2013. Trap-nests for stingless bees (Hymenoptera, Meliponini). Apidologie 44: 29-37.

Oslisly R, 1998. Hommes et milieux à l'Holocène dans la moyenne vallée de l'Ogooué (Gabon). Bulletin de la Société Préhistorique Française 95: 93-105.

Pauly A. 1998. Hymenoptera Apoidea du Gabon. Annales Sciences Zoologiques 282: 1-121.

Pauly A, Fabre Anguilet EC. 2013. Description de Liotrigona gabonensis sp. nov., et quelques corrections à la synonymie des espèces africaines de méli- pones (Hymenoptera: Apoidea: Apinae: Meliponini). Belgian Journal of Entomology 15: 1-13.

Pauly A, Hora ZA. 2013. Apini and Meliponini from Ethiopia (Hymenoptera: Apoidea: Apidae: Apinae). Belgian Journal of Entomology 16: 1-36.

Portugal-Araujo VD. 1963. Subterranean nests of two African stingless bees (Hymenoptera: Apidae). Journal of the New York Entomological Society 71: 130-141.

Roubik, DW. 2006. Stingless bee nesting biology. Apidologie 37: 124-143.

Smith FG. 1954. Notes on the biology and waxes of four species of African Trigona bees (Hymenoptera: Apidae). Proceedings of the Royal Entomological Society of London, Series A, General Entomology 29: 62-70.

Slaa EJ, Chaves LAS, Malagodi-Braga KS, Hofstede FE. 2006. Stingless bees in applied pollination: practice and perspectives. Apidologie 37: 293-315.

Tsalefac M, Hiol Hiol F, Mahé G., Laraque A., Sonwa D, Scholte P., Pokam W, Haensler A., Beyene T, Ludwig F, Mkankam FK, Djoufack VM, Ndjatsana M, Doumenge C. 2015. Climat de l'Afrique centrale : passé, présent et future. pp. 37-52. In Wasseige C, Tadoum M, Eba'a Atyi R, Doumenge C, eds. Les forêts du Bassin du Congo - Forêts et changements climatiques. Weyrich. Belgique. 128 pp.

Tchuenguem FN, Messi J, Pauly A. 2001. Activité de Meliponula erythra sur les fleurs de Dacryodes edulis et son impact sur la fructification. Fruits 56: 179-188.

Tchuenguem FN, Messi J, Pauly A. 2002. Recherches sur l'activité des Apoïdes sauvages sur le maïs à Yaoundé (Cameroun) et réflexions sur la pollinisation des graminées. Biotechnologie, Agronomie, Société et Environnement 6: 87-98.

Wille A. 1983. Stingless bee biology. Annual Review of Entomology 28: 41-64. 